\title{
Strategic Analysis of the Turkish Over-the-Counter Drugs and Non-pharmaceutical Products Market
}

\section{Türkiye Tezgah Üstü Illaç ve Illaç Dışı Ürün Pazarının Stratejik Analizi}

\author{
(1) Merve MEMișoĞLU1*, (1) Ömer BILEN² \\ ${ }^{1}$ Biruni University Faculty of Pharmacy, Department of Pharmacy Management, İstanbul, Turkey \\ 2Bursa Technical University Faculty of Architecture and Design, Department of Urban and Regional Planning, Bursa, Turkey
}

\begin{abstract}
Objectives: The over-the-counter (OTC) drug (i.e., non-prescription drugs) market is growing significantly on a global scale. Our study reviews strategies for OTCs, together with other non-pharmaceutical products, such as herbal products, dietary supplements, and other healthcare products. The aim of this study is to analyze the expanded OTC industry to offer possible strategic solutions for existing problems.

Materials and Methods: We utilized integrated SWOT and Fuzzy Analytic Network Process analyses, together with quantitative analysis covering industry professionals' perspectives.

Results: Our findings showed that the most suitable market strategies are WO2 (i.e., to use information and digital technologies, including mobile applications and social media, to reduce marketing costs), SO2 (i.e., to promote self-medication/self-care to grow the OTC market and invest in information and communication technologies for this purpose), and ST2 (i.e., to improve health literacy and increase access to accurate and understandable information via alternative channels, such as the internet and social media). These key strategies are closely related to the utilization of digital technologies. Other strategies, such as SO1 (i.e., to encourage pharmacists to provide consulting for OTC products, which carry high profitability) and ST1 (i.e., to undertake stakeholder training programs to ensure production quality and introduce safe use to improve community health), were examined in detail, and their outcomes were interpreted in this study.
\end{abstract}

Conclusion: Given the impact of digital transformation, the same strategies can be implemented for other emerging OTC markets. This study underlines the importance of the OTC sector as one of the main drivers for improving community health and reducing health costs.

Key words: Over-the-counter drugs, non-prescription drugs, non-pharmaceutical products, SWOT analysis, Fuzzy Analytic Network Process

ÖZ

Amaç: Global olarak tezgah üstü ilaç (OTC) pazarı önemli ölçüde büyümektedir. Bu bağlamda çalışmamızda, reçetesiz ilaçların yanı sıra, bitkisel ürünler, gıda takviyeleri ve diğer sağlık ürünleri gibi ilaç dışı ürünler de stratejik olarak değerlendirilmiştir. Bu çalışmanın amacı, genişletilmiş OTC endüstrisinin mevcut problemlerine olası stratejik çözümler sunmak için analizini yapmaktır.

Gereç ve Yöntemler: Bu çalışmada entegre SWOT ve Bulanık Analitik Ağ Prosesi analizlerinin yanı sıra sektör profesyonellerinin bakış açılarını kapsayan nicel analizler yapılmıştır.

Bulgular: Çalışmadan elde ettiğimiz bulgular en uygun pazar stratejilerinin WO2 (sosyal medya ve mobil uygulamalar dahil bilişim ve dijital teknolojileri pazarlama maliyetlerini düșürmek için kullanmak), SO2 (OTC pazarının büyümesi için self-medikasyon/kişisel bakımı teşvik etmek ve bu amaçla bilgi ve iletişim teknolojilerine yatırım yapmak), ST2 (sağlık okuryazarlığını geliştirmek için internet ve sosyal medya gibi alternatif kanallar aracılığıyla doğru ve anlaşılır bilgilere erişimi artırmak) olduğunu göstermiştir. Bu kilit stratejiler dijital teknolojilerin kullanımı ile yakından ilgilidir. Ayrıca bu çalışmada SO1 (OTC ürünleri daha yüksek karlılık taşıdığı için eczacıyı danışmanlık yapmaya teşvik etmek), ST1 (üretimde kaliteyi sağlamak ve toplum sağlığını iyileștirmeye yönelik güvenli ilaç kullanımını tanıtmak için, paydaşlara eğitim programları düzenlemek) gibi diğer stratejiler ayrıntılı olarak incelenmiş ve sonuçları yorumlanmıştır.

Sonuç: Dijital dönüşümün etkisi düşünüldügünde, aynı stratejiler gelişmekte olan diğer pazarlar için de uygulanabilir. Bu çalıșma, OTC sektörünün toplum sağlığını geliștiren ve buna bağlı olarak sağlık maliyetini azaltan paydaşlardan biri olarak önemini vurgulamıştır.

Anahtar kelimeler: Tezgah üstü ilaçlar, reçetesiz ilaçlar, ilaç dışı ürünler, SWOT analizi, Bulanık Analitik Ağ Prosesi 


\section{INTRODUCTION}

Over-the-counter (OTC) drugs are sold directly to the consumer without a prescription because they are known to be safe and effective following long-term clinical use. However, similar to regular prescription drugs, OTC drugs may have adverse effects, and they can be misused and abused for their active substances. ${ }^{1-4}$

Non-pharmaceutical products include a wide range of products, such as vitamins, herbal products, dietary supplements, biocidal products licensed by the Ministry of Health $(\mathrm{MoH})$, certain medical devices in pharmaceutical form, medical infant formulas, cosmetics and dermo-cosmetics, and baby food. These products are used in self-care/self-medication and complementary therapy but have not been evaluated as prescription drugs because of their active metabolites.

Regulations applied by the $\mathrm{MoH}$ on non-prescription drugs are rather cumbersome. Pricing decisions for non-pharmaceutical products licensed by the Ministry of Agriculture and Forestry, for example, are simpler and easier to process than those for pharmaceutical products. This issue represents an advantage to non-pharmaceutical product manufacturers.

In Turkey, registration files must be submitted according to Common Technical Documents, similar to EU regulations. Some products are licensed by the $\mathrm{MoH}$, while others are licensed by the Ministry of Agriculture and Forestry. Processes for the same task may differ in terms of duration and other registration requirements. ${ }^{5}$

In 2018, the Turkish pharmaceuticals market increased by $26.1 \%$ to 30.94 billion TL compared with that in 2017. The reasons behind this growth involve price escalation, sales distribution, volume, and new products. The Pharmaceutical Manufacturers Association of Turkey (IEIS) reported that nonpharmaceutical products described as medicinal products made up approximately $31.5 \%$ of the growth in 2018 and were valued at 2.4 billion TL. ${ }^{6}$ These medicinal products are examined in our study.

Unfortunately, the data available do not cover certain products, such as sports nutrition, homeopathic medicinal products, and some herbal products. Therefore, a major problem for all stakeholders, including manufacturing companies, is data quality. This problem contributes to the difficulty of understanding and interpreting the OTC market dynamics of Turkey. ${ }^{7.8}$

The aim of the present study is to analyze Turkey's expanded OTC industry to offer possible strategic solutions for existing problems, including poor data quality and lack of regulation. Thus, the related market is evaluated, and strategies to grow this market are proposed.

\section{MATERIALS AND METHODS}

\section{Data collection}

The data collected consisted of literature and quantitative field research. Only a limited number of studies on OTC/nonpharmaceutical products/self-medication are available in Turkey
(Table 1), and none of them include a strategic market analysis via SWOT-Analytic Network Process (ANP)/Analytic Hierarchy Process (AHP). The available directly related studies only include our previous integrated SWOT and PESTEL analysis ${ }^{7}$ and a qualitative analysis of the Turkish OTC market. ${ }^{8}$ Our previous qualitative analysis was performed using in-depth semistructured interviews of marketing professionals representing OTC and non-pharmaceutical products manufacturers, as well as OTC consultants, in Turkey. ${ }^{8}$

Besides the literature review (Table 1), data were collected from several reports and resources, such as the Turkish Statistical Institute, IEIS, and IMS Health.

The collected data (i.e., related literature, reports, quantitative field research) were used to prepare the SWOT matrix. All data from the literature, except field research, are shown in the SWOT matrix as $\mathrm{L}$. The findings obtained from the online survey are shown as $\mathrm{S}$ (Table 2).

\section{Quantitative survey data}

This study received ethical approval (decision no: 2019/2613, date: 25.02.2019) from the Biruni University Ethics Board. The quantitative assessment included an online survey. The IEIS, AIFD, TiSD, and other related institutes were informed about our study, but only the IEIS agreed to participate. Thus, this survey was pilot-tested on a group of IEIS experts before it was conducted on a group of OTC professionals. Data

\begin{tabular}{|c|c|}
\hline References & Related topic \\
\hline Özcelikay et al. ${ }^{9}$ & $\begin{array}{l}\text { OTC, pharmacists and patients' } \\
\text { perspectives }\end{array}$ \\
\hline Yüksel ${ }^{10}$ & OTC, pharmacists' perspectives \\
\hline Gül et al."1 & Role of pharmacists, OTC purchases \\
\hline Kirgiz ${ }^{12}$ & $\begin{array}{l}\text { Regulations, advertising, self- } \\
\text { medication }\end{array}$ \\
\hline Sencan and Uyar ${ }^{13}$ & $\begin{array}{l}\text { Advertising, pharmacist and industry } \\
\text { perspectives }\end{array}$ \\
\hline Lionis et al. ${ }^{14}$ & OTC prescribing, rational drug use \\
\hline Gülpınar and Özçelikay ${ }^{5}$ & $\begin{array}{l}\text { Regulations, pharmacist and industry } \\
\text { perspectives }\end{array}$ \\
\hline Atikeler and Özçelikay ${ }^{15}$ & Regulations, pricing \\
\hline Oztora et al..$^{16}$ & Self-medication \\
\hline Okyay and Erdoğan ${ }^{18}$ & Self-medication \\
\hline Oral and Özçelikay ${ }^{19}$ & Policies, regulations, ethics \\
\hline Memisoglu ${ }^{8}$ & OTC marketing \\
\hline Memisoglu ${ }^{7}$ & OTC SWOT-PESTEL \\
\hline Cavaco et al. ${ }^{17}$ & Self-medication \\
\hline
\end{tabular}

Gülpınar et al. ${ }^{20}$

Pharmacists' perspectives about nonpharmaceutical products

OTC: Over-the-counter 
collection was conducted between March and June 2019. The main data were collected from a purposive sample, and the target audience included functional managers and senior executives of the OTC industry. The designed questionnaire, which included a SWOT segment, was sent to 55 members, most of whom are manufacturers, through the IEIS. The online questionnaire was also sent to 40 OTC professionals with similar qualifications via Linkedln. In total, 42 participants responded to the questionnaire. Six questionnaires were excluded from the analysis because they included missing answers. Thus, a total of 36 valid questionnaires were included in the sample. This number of participants is considered acceptable because the participants were specifically selected for purposive sampling.

\section{Statistical analysis}

The results were evaluated using advanced statistical tools. The latter incorporated the use of AHP/ANP/ Fuzzy ANP (FANP) methods, which do not require a large number of samples to be statistically significant. ${ }^{21-23}$ Because the participants of the survey were experts with deep knowledge and experience on the topic of interest, we believe that all 36 respondents are qualified and sufficient to provide the required information for the study.

\section{SWOT-FANP}

SWOT, as a decision-making tool, enables the subjective examination of companies, industries, and even countries. However, SWOT presents some disadvantages, such as a lack of weighting factors and ambiguity. Besides SWOT, the FANP is used in this study.

The AHP, which was introduced by Saaty, ${ }^{24}$ is a flexible and effective mechanism for complex decision-making that can help decision-makers set priorities and make the best decisions. The ANP, which is a generalization of AHP, enables the analysis of the interactions of decision criteria. Its basic structures are networks, which undergo interactions and feedback within and between clusters to solve sophisticated decision problems.

ANP and AHP are used for multi-criteria decision-making. However, the former is more appropriate for solving complicated problems because it allows the analyst to capture the complex structures of real interconnections and make predictions with greater accuracy. Saaty suggested the use of ANP to solve the problem of dependence among alternatives or criteria. ${ }^{25,26}$

The ANP method is feasible for fuzzy decision-making problems because it has relatively fewer limitations compared with FANP. Determining the weights and effects of alternative strategic criteria quantitatively by using SWOT alone is impossible. Therefore, ANP/FANP should be combined with SWOT to improve the insufficiency of SWOT data. ${ }^{27}$ Thus, FANP is the preferred research method in our study.

FANP consists of eight steps.

Step 1. Identify SWOT factors and sub-factors. Determine alternative strategies according to the SWOT sub-factors.

Step 2. Develop a matrix using all factors and sub-factors and form a fuzzy scale of 1-9 ( $W_{1}$, i.e., matrix calculation).

Table 2. SWOT matrix for the Turkish OTC industry

Strengths (S)

S1 increasing self-medication/self-care (L)

S2 aging population $(\mathrm{L})$

S3 increasing government support for minimizing reimbursement $(\mathrm{L})$

S4 absolute population growth and increased migration (S)

S5 increasing consumer awareness (S)

S6 pharmacies as distribution channels $(\mathrm{L})$

S7 qualified people in the OTC industry (S)

S8 possible synergistic effects of non-pharmaceutical products (S)

S9 greater profitability compared with prescription drugs for the pharmacist (S)

Opportunities (O)

01 rapid market growth (S)

$\mathrm{O} 2$ rapid developments in information and communication

technologies (S)

O3 R\&D and innovation (S)

O4 direct-to-consumer advertising ( $L$ )

05 pharmacists as consultants/salespersons $(\mathrm{L})$

O6 company mergers and acquisitions $(L)$

\section{Weaknesses (W)}

W1 healthcare professionals' negative perception of herbal products and dietary supplements (L)

W2 information pollution caused by companies (S)

W3 lack of education of related stakeholders (S)

W4 lack of OTC regulations and certain classifications (L)

W5 non-regular market; difficulty obtaining clear data $(L)$

W6 rising costs $(\mathrm{S})$

W7 lack of direct-to-consumer advertising for non-prescription drugs (S)

W8 absence of pharmacist's role as a consultant $(L)$

W9 unwillingness of healthcare professionals to recommend and provide prescriptions (S)

Threats ( $\mathrm{T}$ )

T1 economic crisis, exchange rate fluctuations $(L)$

T2 poor-quality production for some non-pharmaceutical products $(L)$

T3 poor health literacy $(\mathrm{L})$

T4 media disinformation (S)

T5 lack of direct-to-consumer advertising for non-prescription drugs (S)

T6 market penetration difficulties, highly competitive environments (S) 
Step 3. Determine the inner dependence matrix of each SWOT factor with a fuzzy scale of 1-9 with respect to other factors by using a schematic representation of inner dependence among the SWOT factors ( $W_{2}$, i.e., matrix calculation).

Step 4. Determine the interdependent priorities of the SWOT ( $W_{\text {SWOT }}$ factors $\left.=W_{1} \times W_{2}\right)$.

Step 5. Determine the local importance degrees of the SWOT sub-factors with a fuzzy scale of 1-9 ( $W_{\text {swot }}$ sub-factors, local).

Step 6. Determine the global importance degrees of the SWOT sub-factors $\left(\mathrm{W}_{3}\right.$ global sub-factors of SWOT $=\mathrm{W}_{\text {factors }} \times \mathrm{W}_{\text {relative }}$ sub-factors of SWOT).

Step 7. Determine the importance degrees of the strategic options with respect to each SWOT sub-factor with a fuzzy scale of 1-9 $\left(\mathrm{W}_{4}\right)$.

Step 8. Determine the overall priorities of the strategic options considering internal relations among SWOT factors $\left(\mathrm{W}_{\text {alternatives }}=\mathrm{W}_{4} \times \mathrm{W}_{3}\right.$ global sub-factors).

Saaty ${ }^{28}$ reported that the acceptable limit of the consistency ratio (CR) is 0.10 or less. Thus, the $C R$ of the matrix was checked. ${ }^{28}$ The AHP template developed by SCB Associates Ltd. was used for statistical analysis.

A schematic structure of the SWOT analysis was established. The related SWOT criteria and sub-criteria are shown in Figure 1. Strategies were prioritized on the basis of the FANP approach.

\section{RESULTS}

The demographics of the participants were summarized in Table 3. The respondents comprised $66.7 \%$ males and $33.3 \%$ females. Among the 36 respondents, $69.5 \%$ were aged $31-50$ years, $22.2 \%$ were aged $51-60$ years, and $8.3 \%$ were aged 26 -
30 years. Experience could be divided into two major groups of 6-10 years (33.4\%) and $<21$ years (27.8\%). The majority of the participants worked in the marketing and sales department of the OTC industry (47.2\%), and others worked in the regulatory affairs department (25\%). The sample also included executives (16.7\%) and managers from the medical department (11.1\%) of

Table 3. Demographic characteristics of the participants

\begin{tabular}{|c|c|c|c|}
\hline & & $\begin{array}{l}\text { Percentage } \\
\%\end{array}$ & $\begin{array}{l}\text { Frequency } \\
\mathrm{n}\end{array}$ \\
\hline \multirow{2}{*}{ Gender } & Female & 33.3 & 12 \\
\hline & Male & 66.7 & 24 \\
\hline \multirow{4}{*}{ Age } & $26-30$ & 8.3 & 3 \\
\hline & $31-40$ & 30.6 & 11 \\
\hline & $41-50$ & 38.9 & 14 \\
\hline & $51-60$ & 22.2 & 8 \\
\hline \multirow{4}{*}{$\begin{array}{l}\text { Years of } \\
\text { experience }\end{array}$} & $6-10$ & 33.4 & 12 \\
\hline & $11-15$ & 19.4 & 7 \\
\hline & $16-20$ & 19.4 & 7 \\
\hline & $21<$ & 27.8 & 10 \\
\hline \multirow{5}{*}{ Department } & $\begin{array}{l}\text { Regulatory affairs/ } \\
\text { market access }\end{array}$ & 25 & 9 \\
\hline & Marketing & 33.3 & 12 \\
\hline & Sales & 13.9 & 5 \\
\hline & Medical & 11.1 & 4 \\
\hline & Executives & 16.7 & 6 \\
\hline
\end{tabular}

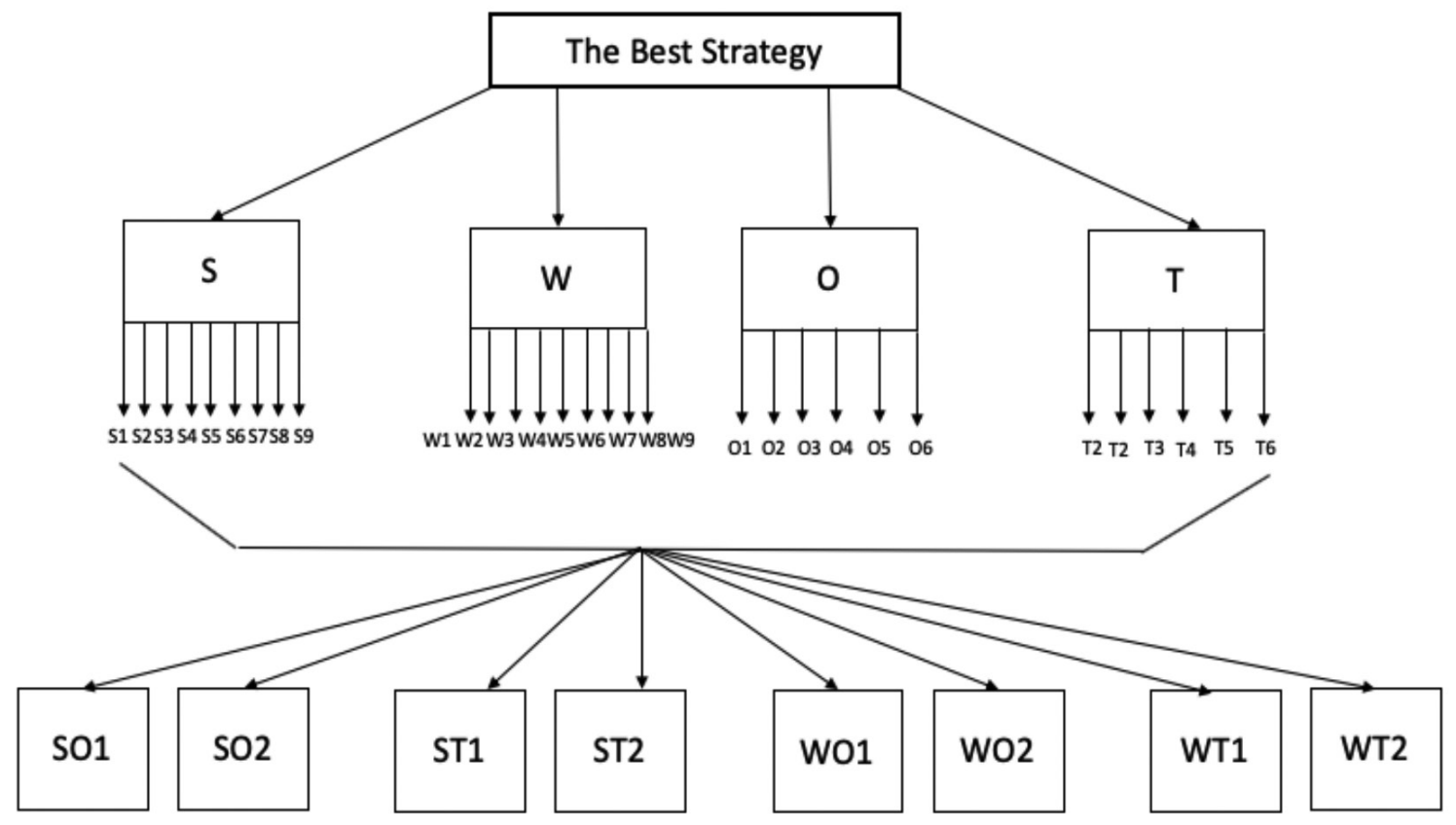

Figure 1. FANP model for the selection of the best strategies FANP: Fuzzy Analytic Network Process 
the OTC sector. All participants were functional managers or senior executives. Unlike in our previous study, ${ }^{8}$ both marketing professionals and managers specializing in other departments of the companies participated in our study.

Findings from the survey and other sources are consolidated in the SWOT matrix, as shown in Table 2.

Each SWOT element was checked for consistency. The CR was calculated to be less than 0.1 (10\%), which is acceptable. Thus, reexamination was unnecessary because passing the consistency theory.

The fuzzy linguistic variables are shown in Table 4.

The weighting factor of FANP is essential to achieve a strategic choice. The impact of each group was analyzed on all other factors by using pairwise comparisons to obtain relativeimportance weights (Table 5). Some required questions, such as "How important is strength when it is compared with a weakness?" and "How important is an opportunity when it is compared with a threat?" were used.

In this study, all possible criteria and interactions were considered (Table 6). The following table summarizes possible strategies for the Turkish OTC industry, and each strategy is individually examined (Table 7 ).

Table 4. Linguistic variables

\begin{tabular}{|c|c|c|c|c|c|}
\hline & \multirow{2}{*}{$\begin{array}{l}\text { Saaty's } \\
\text { scale }\end{array}$} & \multirow{2}{*}{ TFN } & \multicolumn{3}{|c|}{ Definition of TFN } \\
\hline & & & Bottom & Medium & Top \\
\hline Equally preferred & 1 & 1 & 1 & 1 & 1 \\
\hline $\begin{array}{l}\text { Equally to moderately } \\
\text { preferred }\end{array}$ & 2 & 2 & 1 & $3 / 2$ & $3 / 2$ \\
\hline Moderately preferred & 3 & 3 & 1 & 2 & 2 \\
\hline $\begin{array}{l}\text { Moderately to strongly } \\
\text { preferred }\end{array}$ & 4 & 4 & 3 & $7 / 2$ & 4 \\
\hline Strongly preferred & 5 & 5 & 3 & 4 & $9 / 2$ \\
\hline $\begin{array}{l}\text { Strongly to very } \\
\text { strongly preferred }\end{array}$ & 6 & 6 & 3 & $9 / 2$ & 5 \\
\hline Very strongly preferred & 7 & 7 & 5 & $11 / 2$ & 6 \\
\hline $\begin{array}{l}\text { Very strongly to } \\
\text { extremely preferred }\end{array}$ & 8 & 8 & 5 & 6 & 7 \\
\hline Extremely preferred & 9 & 9 & 5 & 7 & 9 \\
\hline
\end{tabular}

TFN: Triangular fuzzy number

Table 5. Pairwise comparison of SWOT groups without interdependencies

\begin{tabular}{|c|c|c|c|c|c|c|c|}
\hline & \multirow{2}{*}{$\mathrm{S}$} & \multirow{2}{*}{ W } & \multirow{2}{*}{0} & \multirow{2}{*}{$\mathrm{T}$} & \multicolumn{3}{|c|}{ TFN importance of SWOT factors } \\
\hline & & & & & Bottom & Medium & Top \\
\hline Strengths (S) & 1.000 & 3.000 & 2.000 & 2.000 & 0.250 & 0.352 & 0.352 \\
\hline Weaknesses (W) & - & 1.000 & 0.500 & 0.500 & 0.250 & 0.166 & 0.166 \\
\hline Opportunities (O) & - & - & 1.000 & 1.000 & 0.250 & 0.241 & 0.241 \\
\hline Threats $(T)$ & - & - & - & 1 & 0.250 & 0.241 & 0.241 \\
\hline
\end{tabular}

TFN: Triangular fuzzy number
S01: The profitability of OTC products will increase the consultation capacity of the pharmacist. Thus, companies may need to involve pharmacists in their marketing strategies. This strategy maybe effective if the prejudice of pharmacists against OTC drugs and non-pharmaceutical products is reduced and knowledge about these products is increased. Therefore, improving the quality of training and supporting training with digital technologies are important.

S02: Self-medication and self-care are increasing rapidly on a global scale. ${ }^{29}$ In line with these developments, the promotion of self-medication/self-care may be expected to grow the OTC market in Turkey. The expansion of health and wellness trends will also grow the market. The government should support OTC products because these products do not require reimbursement. Therefore, support for these products may be a good strategy to support self-medication. However, increasing the health literacy of the public is necessary to avoid the incidence of serious adverse reactions.

ST1: Poor-quality products of some non-pharmaceuticals present a great threat to the OTC industry. Education and training are vital in the eco-system. As one will increase the qualified personnel in the OTC industry, production quality will increase via the application of good manufacturing practice standards and inevitably lead to the safe use of these products.

ST2: Assuming that companies provide correct information, access to this information and diversification of channel sources, such as the internet, can increase health literacy. Increased use of advertising and various information technologies will also promote self-medication.

W01: Poor-quality production can be overcome by investing in innovation. Companies should prioritize innovation and spend on R\&D. As the active metabolites of non-prescription drugs are well-known, the available innovations are somehow limited. The main innovation practices of OTCs are combination products, different dosage forms, and line extension.

Differentiation from competitors is an essential factor in building a successful brand and increasing market share. According to our survey findings, innovation is best when using advanced technology and creative communication strategies (72.2\%). Sector participants in our survey also emphasized efficacy, quality, and corporate reputation (42.9\%) as key factors in building a strong brand.

W02: In times of economic volatility, all pharma companies and consumers strive to survive. External factors, such as 
the economic crisis and exchange rate fluctuations, could increase costs for companies. As companies cannot directly intervene in macro factors, such as economic crises, they can instead develop counter-strategies by introducing cost-saving measures. They may, for example, switch from traditional to digital media, thereby taking advantage of the benefits of social media. At this point, effective content management will gain importance for OTC companies.

WT1: Advertising restrictions may be effective in improving the negative perspectives of physicians and pharmacists.
Advertising control is important for patient safety, especially when literacy and/or educational levels vary among the public. In our study, the participants agreed that environmental, economic, and social sustainability, which also cover the safety of non-pharmaceutical products $(86.1 \%)$, should be among the priorities of pharma companies (88.8\%).

Direct-to-consumer advertising for prescription and nonprescription drugs is banned in Turkey ${ }^{30}$ but freely available for non-pharmaceutical products. No specific regulation regarding the use of social media by companies is yet available. The

Table 6. Importance of the criteria and sub-criteria of the SWOT analysis

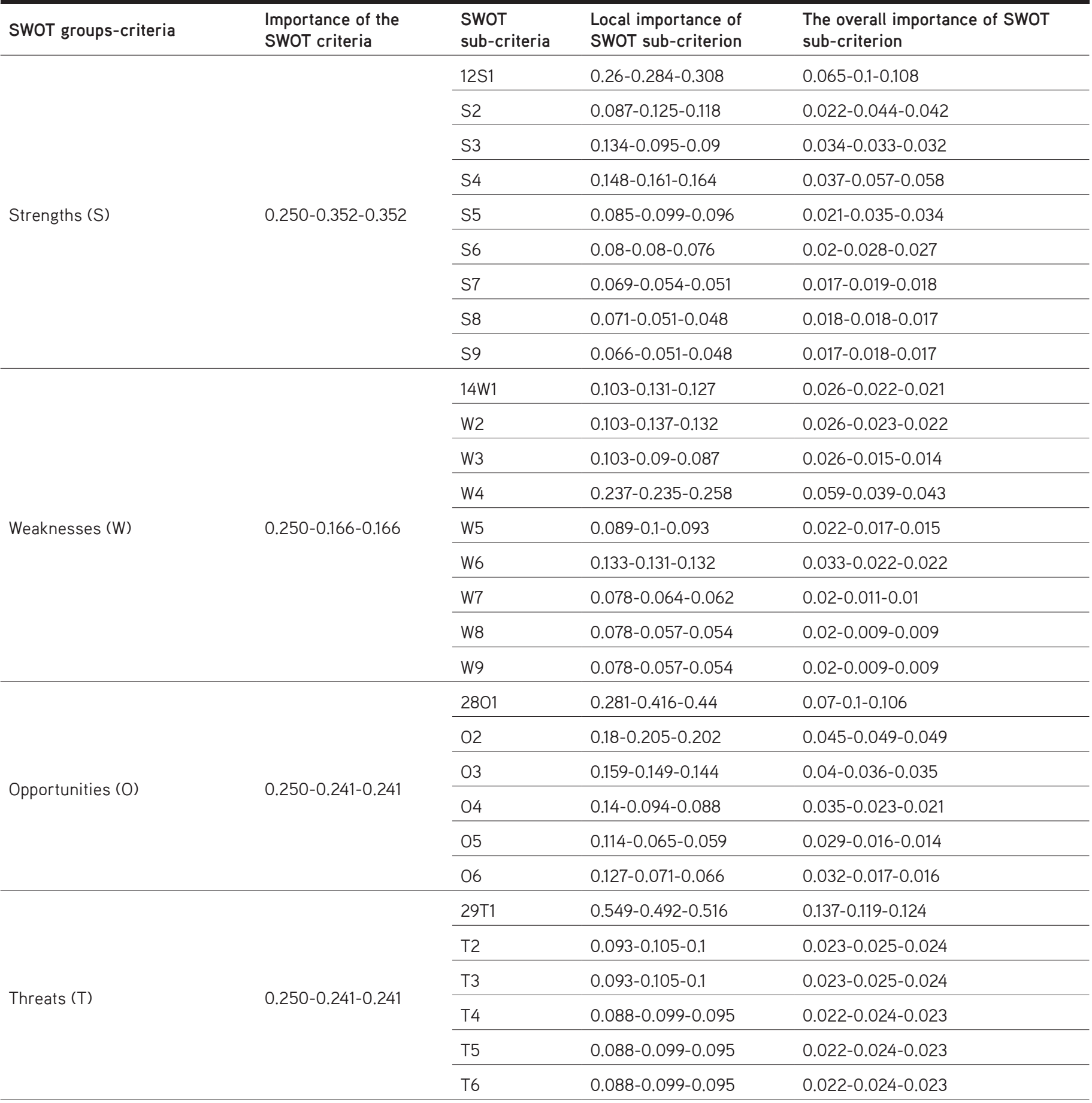


lack of direct-to-consumer advertising can be turned into an advantage for public health, especially among groups with low health literacy. This strategy may be a strong point for Turkey, where nearly half of the population has limited health literacy. ${ }^{31}$ Companies should prioritize the disclosure of accurate information to target consumer groups. In Turkey, new regulations, as well as a proper classification for OTCs, are necessary. OTC ads should also be organized in this context.

According to Table 8, 9, after prioritizing the defined strategies, we can conclude that WO2, which has the highest weight of 0.163 , is the best market strategy. Other potential strategies include SO2 (weight, 0.161) and ST2 (weight 0.160). In terms of weight, these three strategies highly similar to each other.

\section{DISCUSSION}

The survey results revealed that the strengths of the OTC industry are multifold and highly variable. Increased consumer awareness and a tendency to self-medicate are among the more noteworthy findings. Self-medication/self-care presents a number of important advantages, such as reduced government spending. ${ }^{29}$ However, this same benefit may also pose a serious threat to this market. OTC drugs have potential risks, such as misdiagnosis, drug misuse and abuse, and polypharmacyinduced drug-drug interactions, especially in elderly patients.

Pharmacovigilance, also known as drug safety, for prescription drugs has been implemented since 2005. However, this regulation has yet to be established clearly for other types

\section{Table 7. Strategies for the Turkish OTC industry}

SO strategies

SO1 to encourage pharmacists to provide consulting as OTC products carry higher profitability

SO2 to promote self-medication/self-care to grow the OTC market and invest in information and communication technologies for this purpose

\section{ST strategies}

ST1 to undertake stakeholder training programs to ensure production quality and introduce safe use for improved community health

\section{WO strategies}

WO1 to invest in R\&D and innovation to overcome poor-quality manufacturing and increase the available variety of medical treatments

WO2 to use IT and digital technologies, including social media and mobile applications, to reduce marketing costs

\section{WT strategies}

WT1 to limit direct-to-consumer advertising for non-pharmaceutical products to improve negative views of physicians and pharmacists. This limitation may be transformed into an advantage for communities with low health literacy

ST2 To improve health literacy and increase access to accurate and understandable information via alternative channels, such as the internet and social media

OTC: Over-the-counter

Table 8. Elements of the fuzzy matrix $\mathrm{W} \sim 4$

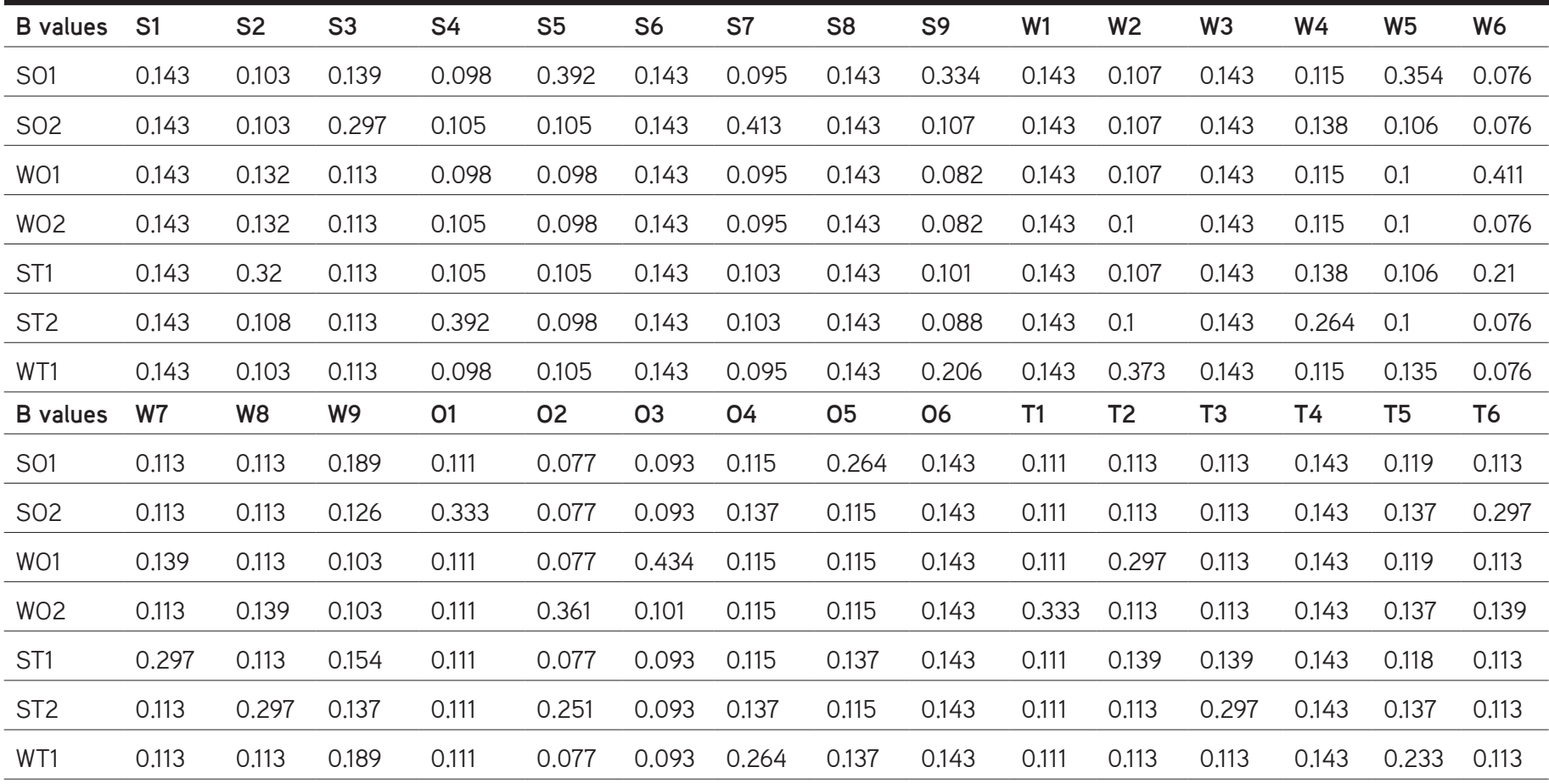


Table 8. Continued

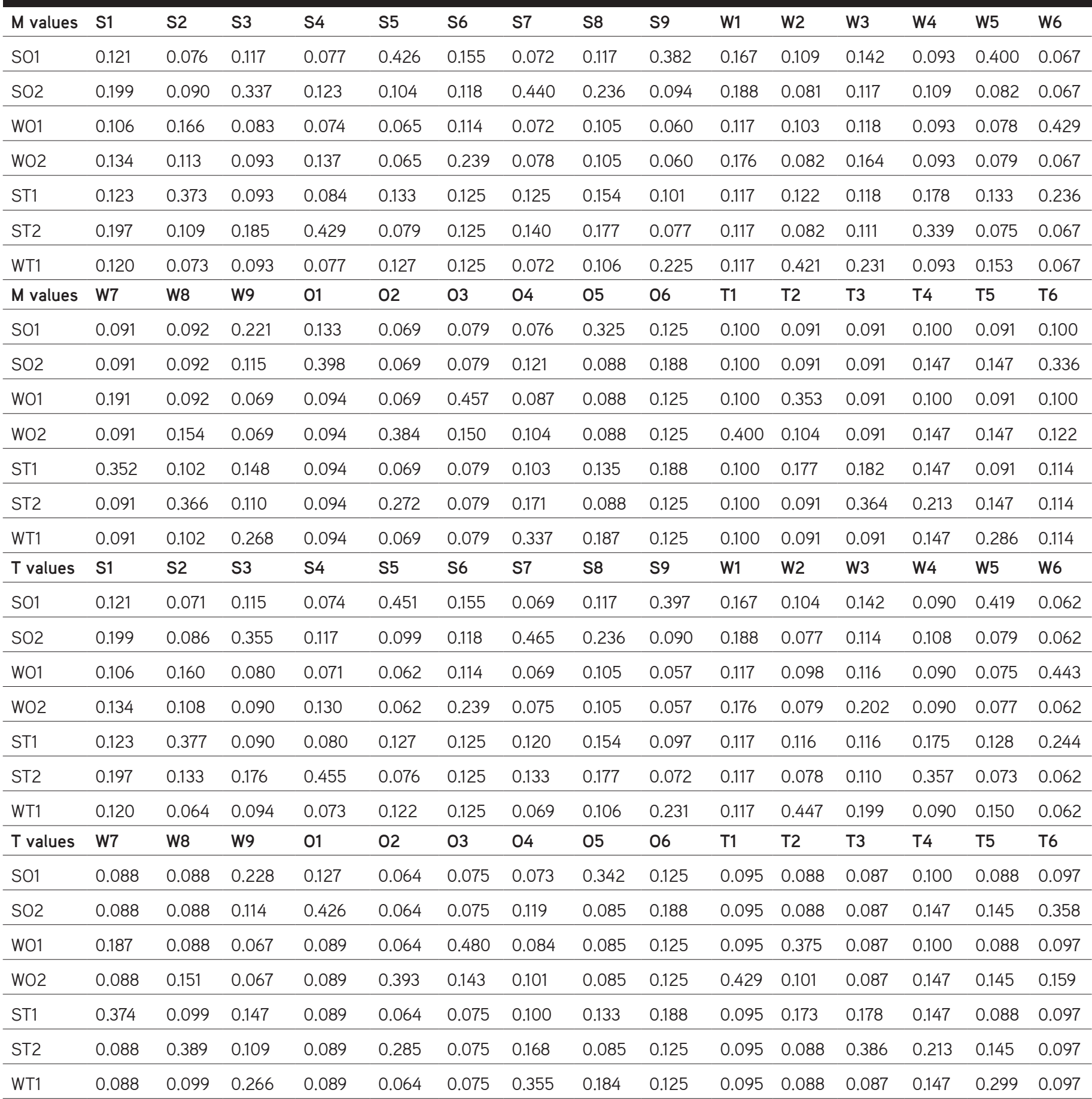

of drugs. For example, healthcare professionals can only report hepatotoxicity and nephrotoxicity to the $\mathrm{MoH}$ for herbal medicines. The concept of pharmacovigilance should cover all types of products in Turkey. Indeed, in our study, $86.1 \%$ of the participants agreed that the vigilance system should be extended to non-pharmaceutical products.

The environmental impacts of non-pharmaceutical products remain unknown. Although some global companies attach importance to sustainability, the government should promote campaigns related to the ecological footprint, climate change awareness, and eco-pharmacovigilance. According to our survey, $88.8 \%$ of the participants confirmed that environmental, economic, and social sustainability should be among the priorities of companies.

In this study, we stress the significant role of pharmacists. Pharmacists are the most accessible healthcare professionals and can improve medication adherence and decrease selfmedication risk and cost. ${ }^{29,32,33}$ Thus, pharmaceutical companies 
Table 9. Priorities of the alternative strategies

\begin{tabular}{lll} 
Strategy & Weight & Ranking/priority \\
\hline SO1 & 0.131 & 4 \\
\hline SO2 & 0.161 & 2 \\
\hline W01 & 0.130 & 6 \\
\hline W02 & 0.163 & 1 \\
\hline ST1 & 0.131 & 5 \\
\hline ST2 & 0.160 & 3 \\
\hline WT1 & 0.126 & 7 \\
\hline
\end{tabular}

should liaise with pharmacists to develop marketing strategies that could result in safe and ethically correct results to build consumer awareness.

The pharmaceutical industry has high-quality production capabilities, but not all non-pharmaceutical products are manufactured with high-quality standards. Kotecki ${ }^{34}$ found that medical factors, such as the active ingredients of the products, clinical studies, and information obtained from scientific references, are quite effective in supporting pharmacists' OTC product decisions. Therefore, companies should focus on manufacturing quality and evidence-based information in efforts to improve community health and develop a good impression for healthcare professionals. ${ }^{34}$

Unlike in previous SWOT analyses of the OTC market, Dzeparoski et al. ${ }^{35}$ underlined qualified personnel as a strength factor and market growth as an opportunity. These results are similar to our findings. An earlier study on the SWOT analyses of traditional Chinese medicine reported government policy support as an opportunity, ${ }^{36}$ similar to our results.

The first three strategies highlighted in our research are related to the advantages of utilizing digital technologies. Technology is crucial for innovation and differentiation in this competitive environment. ${ }^{37}$ In this context, companies should adopt the rapid development of information and communication technologies to educate all stakeholders. While the internet can be a highly effective channel with which to reach the consumer and, thus, increase their awareness, one must also be aware of the dangers of information pollution. Hence, companies should conduct full diligence to protect the public from information pollution.

Turkish legislation prohibits the sale of prescription and nonprescription drugs via the internet or any other electronic media. ${ }^{38}$ Companies should utilize digital communication options by complying with relevant laws and regulations.

\section{Study limitations}

The definition of the term "OTC" is ambiguous in Turkey because of the lack of regulation of some drugs and the slow progress of the diversification of sales channels. Thus, our study refers to all products sold in pharmacies, including non-prescription drugs and non-pharmaceutical products but excluding prescription drugs, as OTC products. ${ }^{7,8}$
Our study is limited by its small sample size, which prohibits quantitative analyses. The questionnaire was sent to IEIS members and some experts with similar qualifications via Linkedln. Only 36 participants completed all of the questions.

The AHP, ANP, and FANP methods used in our study do not require a large number of samples to be statistically significant. ${ }^{21-23}$ Additionally, the participants of the survey were experts with deep knowledge and experience on the OTC and pharmaceutical industry. All 36 responders were qualified to provide the required information for this study.

\section{CONCLUSION}

Our study is among the first detailed strategic studies to use integrated SWOT and FANP to analyze the Turkish OTC market.

We strongly believe that the transformation of the OTC industry can contribute to the health of society. Companies must allocate a budget for training as part of their marketing activities. The training program should be directed to all stakeholders, such as company professionals, physicians, pharmacists, and consumers.

Companies should also increase the production quality of non-pharmaceutical products and expand their portfolio with innovative products. In addition, they should avoid aggressive and misleading advertising to improve the health literacy of consumers.

Our main finding is that the utilization of digital technologies is within the scope of priority strategies for the OTC market. Our study has clearly shown that all of the best possible strategies (i.e., WO2, SO2, ST2) highlight the importance of investing in digital technologies. The development of social media, websites, microsites, and, in particular, the related content management, are indispensable for utilizing the most appropriate strategies. The widespread utilization of digital technologies in many areas, starting from R\&D, the supply chain, and production to marketing and corporate communications, will accelerate the development of OTC companies. The effective use of digital platforms will also contribute to increasing health literacy in various communities and raise awareness of OTC consumption and self-medication among consumers.

\section{ACKNOWLEDGMENTS}

The authors would like to thank the IEIS for its contributions and all of the participants who shared their valuable opinions in this study.

Conflicts of interest: No conflict of interest was declared by the authors. The authors alone are responsible for the content and writing of the paper.

\section{REFERENCES}

1. Hughes CM, McElnay JC, Fleming GF. Benefits and risks of selfmedication. Drug Saf. 2001;24:1027-1037.

2. Chambers $\mathrm{C}$. Over-the-counter medications: risk and safety in pregnancy. Semin Perinatol. 2015;39:541-544. 
3. Barrenberg E, Garbe E. Use of over-the-counter (OTC) drugs and perceptions of OTC drug safety among German adults. Eur J Clin Pharmacol. 2015;71:1389-1396.

4. Benotsch EG, Koester S, Martin AM, Cejka A, Luckman D, Jeffers AJ. Intentional misuse of over-the-counter medications, mental health, and polysubstance use in young adults. J Community Health. 2014;39:688695.

5. Gülpınar G, Özçelikay G. OTC drug regulations in Turkey: the opinions of community pharmacists and drug industry. Turk J Pharm Sci. 2015;12:1829.

6. Turkish Pharmaceutical Market Report 2018. Pharmaceutical Manufacturers Association of Turkey-ïlaç Endüstrisi İşverenler Sendikası (IEIS); 2019.

7. Memisoglu M. Evaluating of Turkish OTC and Non-Pharmaceutical Products Industry Using an Integrated SWOT and PESTEL Analysis, $12^{\text {th }}$ ISOPS Proceedings, Ankara 26-29 June 2018, p.55.

8. Memisoglu M. Marketing communications for over-the-counter drugs and non-pharmaceutical products: the professionals' perspective. Int J Healthc Manag. 2017;13:1-8.

9. Özcelikay G, Özcömert GH, Sar S, Asil E. A Study on non-prescription drugs from the view of the pharmacists and the patients in Turkey. FABAD J Pharm Sci. 1999;24:1-5.

10. Yüksel CA. Eczacıların reçetesiz ilaçların karşı tutumlarının genel tutum ortalamasından farkı ve tutumlarla demografik ve eczane özellikleri arasında ilişkinin incelenmesi üzerine pilot bir araştırma. J School Bus Adm Istanbul Uni. 2001;12:41-52.

11. Gül H, Omurtag G, Clark PM, Tozan A, Ozel S. Nonprescription medication purchases and the role of pharmacists as healthcare workers in selfmedication in Istanbul. Med Sci Moni. 2007;13:9-14.

12. Kirgiz AC. The current condition of the OTC market in Turkey, and solution proposals for debates in its direct introduction to consumers. Int J Econ Commer Manag. 2014;2:1-15.

13. Sencan N, Uyar M. Direct to consumer drug advertisements and patient rights: A qualitative research. Marmara Pharm J. 2014;18:164-176.

14. Lionis C, Petelos E, Shea S, Bagiartaki G, Tsiligianni IG, Kamekis A, Tsiantou V, Papadakaki M, Tatsioni A, Moschandreas J, Saridaki A, Bertsias A, Faresjö T, Faresjö A, Martinez L, Agius D, Uncu Y, Samoutis G, Vlcek J, Abasaeed A, Merkouris B. Irrational prescribing of over-thecounter (OTC) medicines in general practice: testing the feasibility of an educational intervention among physicians in five European countries. BMC Fam Pract. 2014;15:34.

15. Atikeler EK, Özçelikay G. Comparison of pharmaceutical pricing and reimbursement systems in Turkey and certain EU countries. Springer Plus. 2016;5:1876.

16. Oztora S, Nepesova G, Caylan A, Dagdeviren HN. The practice of selfmedication in an urban population. Biomed Res. 2017;28:6160-6164.

17. Cavaco AM, Sozen-Sahne B, Ulutas-Deniz E, Yegenoglu S. Selfmedication and non-prescription drug counseling: Illustrating profession uncertainty within Turkish pharmacy practice. Res Social Adm Pharm. 2018;14:718-726.

18. Okyay RA, Erdoğan A. Self-medication practices and rational drug use habits among university students: a cross-sectional study from Kahramanmaraş, Turkey. Peer J. 2017;5:3990.
19. Oral M, Özçelikay G. Ethical overview of pharmaceutical industry policies in turkey from various perspectives. Turk J Pharm Sci. 2017;14:264-273.

20. Gülpınar G, Dolu S, Uzun MB, Özçelikay G. A study on determining the opinions and attitudes of community pharmacists about nonpharmaceutical medicinal products. Marmara Pharm J. 2019;23:146-154.

21. Duke JM, Aull-Hyde R. Identifying public preferences for land preservation using the analytic hierarchy process. Ecol Econ. 2002;42:131-145.

22. Shrestha RK, Alavalapati JR, Kalmbacher RS. Exploring the potential for silvopasture adoption in south-central Florida: an application of SWOTAHP method. Agricl Syst. 2004; 81:185-199.

23. Gupta KP, Manrai R. Prioritizing factors affecting the adoption of mobile financial services in emerging markets-a fuzzy ahp approach. in performance prediction and analytics of fuzzy, reliability and queuing models. Singapore: Springer; 2019:55-81.

24. Saaty TL. Decision making-the analytic hierarchy and network processes (AHP/ANP). J Syst Sci Syst. 2004;13:1-35.

25. Chang HH, Huang WC. Application of a quantification SWOT analytical method. Math Comput Model. 2006;43:158-169.

26. Saaty TL. Decision making with dependence and feedback: the analytic network process. Pittsburgh: RWS Publications; 1996.

27. Saaty TL. Decision making with dependence and feedback. The analytic network Process. Pittsburgh PA: RWS Publications; 2001.

28. Saaty TL. The analytical hierarchy process, planning, priority. Resource allocation. New York, USA: RWS Publications; 1980

29. Bell J, Dziekan G, Pollack C. Self-care in the twenty first century: a vital role for the pharmacist. Adv Ther. 2016;33:1691-1703.

30. Turkish Ministry of Health. Regulation on Promotional Activities of the Human Medicinal Products. Legislation of the Republic of Turkey. The Official Gazette of Republic of Turkey 03.07.2015, 29405, 2015.

31. Ozdemir H, Alper Z, Uncu Y, Bilgel N. Health literacy among adults: a study from Turkey. Health Educ Res. 2010;25:464-477.

32. Hanna LA, Hughes CM. 'First, do no harm': factors that influence pharmacists making decisions about over-the-counter medication. Drug Saf. 2010;33:245-255.

33. Wertheimer Al, Serradell J. A discussion paper on self-care and its implications for pharmacists. Pharm World Sci. 2008;30:309-315.

34. Kotecki JE. Factors related to pharmacists' over-the-counter recommendations. J Community Health. 2002;27:291-306.

35. Dzeparoski M, Trajkovic-Jolevska S. Analysis of marketing strategy for food supplements and over-the-counter medicines. Open Access Maced J Med Sci. 2016;4:499.

36. Tang H, Huang W, Ma J, Liu L. SWOT analysis and revelation in traditional Chinese medicine internationalization. Chin Med. 2018;13:5.

37. Huang KF. Technology competencies in competitive environment. J Bus Res. 2011;64:172-179.

38. Law on Pharmacists and Pharmacies (Eczacılar ve Eczaneler Hakkında Kanun), The Official Gazette of Republic of Turkey, 18.12.1953, No. 6197. 